\title{
Isolation and evaluation of the cytotoxic properties of peroxisomicine isomers from Karwinskia parvifolia
}

\author{
${ }^{1}$ Verónica Rivas, ${ }^{3}$ Gabriel Cuevas, Lourdes Garza, and * ${ }^{1}$ Noemí Waksman \\ ${ }^{1}$ Departamento de Química Analítica, ${ }^{2}$ Departamento de Farmacología y Toxicología, \\ Facultad de Medicina, Universidad Autónoma de Nuevo León, \\ Monterrey Nuevo León, México, P. O. Box 2316 \\ 3 Instituto de Química, UNAM, México \\ E-mail:nwaksman@fm.uanl.mx
}

This paper is dedicated to Rosa M. de Lederkremer in her $70^{\text {th }}$ birthday

\begin{abstract}
A new compound with a peroxisomicine (dimeric hydroxyanthracenone type) structure was isolated from Karwinskia parvifolia and denominated peroxisomicine A4 (PA4). The stereochemistry of the stereogenic centers of this compound and the previously isolated peroxisomicine A3 (PA3, 3) was elucidated using CD, ${ }^{13} \mathrm{C}$ NMR and ${ }^{1} \mathrm{H}$ NMR spectra. Four peroxisomicine stereoisomers were cytotoxic to Chang and HepG2 Liver cells. Only peroxisomicine A1 (PA1, 1) and A3 (PA3, 3) showed selective toxicity. Since 1 and 3 are epimers at C-3' the cytotoxicity results suggest that the stereochemistry at this site may be involved in the cytotoxic properties of these compounds.
\end{abstract}

Keywords: Peroxisomicines, stereochemistry, cytotoxicity, Karwinskia

\section{Introduction}

The genus Karwinskia (Rhamnaceae) is a taxon constituted basically by shrubs that grow in the Southern United States, Mexico, Central America, Colombia, Cuba, Haiti and Dominican Republic. This genus includes 15 species of which are found in Mexico. Most of these species have been reported as poisonous plants. ${ }^{2}$ Phytochemically, these plants are characterized by their content of toxic dimeric hydroxyanthracenones. ${ }^{3} \mathrm{Up}$ to date, 15 different hydroxyantracenones from roots and fruits of $K$. humboldtiana and K. parvifolia have been isolated and characterized. All the compounds that have been isolated are optically active mainly due to the presence of different stereogenic elements, namely two or three chiral centers 
and axes. Among these compounds, the peroxisomicines have been the subject of different studies on account of their biological activity. Three different stereoisomers of peroxisomicine have been isolated, identified and named as peroxisomicine A1 (1), A2 (2) and A3 (3) (Figure 1).

PA1 $\mathrm{R}_{1}, \mathrm{R}_{3}=\mathrm{OH}, \mathrm{R}_{2}, \mathrm{R}_{4}=\mathrm{Me}$

PA2 $\mathrm{R}_{1}, \mathrm{R}_{4}-\mathrm{OH}, \mathrm{R}_{2}, \mathrm{R}_{3}-\mathrm{Mc}$

PA3 $R_{1}, R_{4}=\mathrm{Me}, \mathrm{R}_{2}, \mathrm{R}_{3}=\mathrm{OH}$

PA4 $R_{1}, R_{3}=M e, R_{2}, R_{4}=O H$

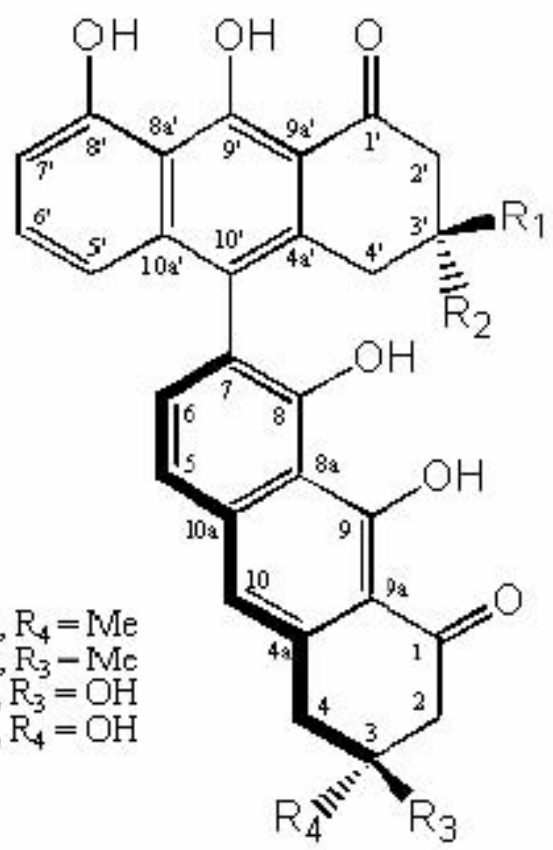

Figure 1. Structures of Peroxisomicines.

Peroxisomicine A1 (PA1) has demonstrated selective in vitro cytotoxicity to neoplastic cells derived from hepatic, pulmonary and colonic tissues. It induces apoptosis in human promyelocytic leukemia cells (HL-60) and is an inhibitor of topoisomerase II, as is the case of other anticancer drugs. This suggests that these processes may play a role in the induction of tumor cell death by PA1.

On this study, a novel peroxisomicine stereoisomer, named peroxisomicine A4 (PA4, 4) has been isolated from K. parvifolia. Cytotoxicity studies for the four stereoisomers is also reported herein.

\section{Results and Discussion}

${ }^{1} \mathrm{H}$ NMR and ${ }^{13} \mathrm{C}$ NMR of the newly isolated compound are almost identical to the spectra obtained from the three peroxisomicines previously identified. Therefore, it can be concluded that the newly isolated compound is of peroxisomicine-type, a dimeric hydroxyanthracenone. The absolute stereochemistry of PA1 (1) and PA2 (2) were recently be resolved by means of degradative procedures and quantum chemical circular dichroism calculations. ${ }^{9,10}$ As a result of 
these investigations, 1 resulted to be the P, 3S, 3'S isomer and 2 the P, 3R, 3'S isomer. 3 and 4, display the same CD spectra as 1 and 2 (Figure 2); considering that similarly coupled dihydroxyanthracenones possessing the same axial stereochemistry display CD spectra of the same type, the biaryl linkage in $\mathbf{3}$ and $\mathbf{4}$ should have similar stereochemistry; therefore $\mathbf{3}$ and $\mathbf{4}$ are also $(\mathrm{P})$-atropo-isomers as shown on figure 1.

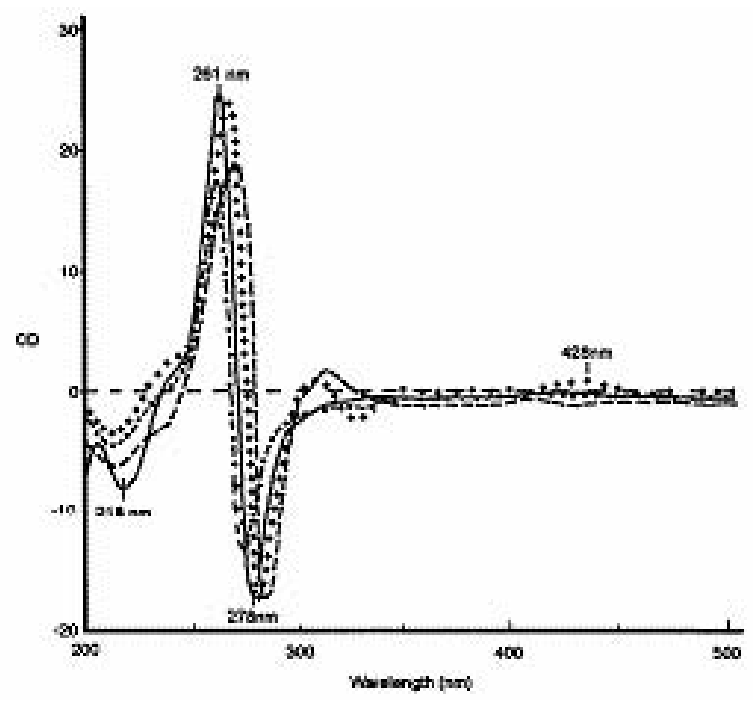

Figure 2. CD spectra data for PA1 ( ), PA2 (---), PA3 (++), and PA4 (...).

Following the nomenclature used previously, the new compound was named peroxisomicine A4 (PA4). From our previous results, it can be determined that the configuration at C-3' is R both in 3 and 4. Molecular models were built using the AM1 semiempirical method and computer-generated minimum energy conformations were used as a basis for calculation of the vicinal coupling constants. The calculated conformations yielded the internuclear distances that were compared with the nOe differences; the nOe interactions seen between H-4'ax and H-6 and H-4'eq and H-8 in the H NMR spectra of both compounds confirms that C-3' has R configuration both in $\mathbf{3}$ and $\mathbf{4}$. Therefore $\mathbf{3}$ and $\mathbf{4}$ must be epimers at C-3. Due to the limited availability of these two compounds, it was not possible to conduct degradation procedures with them. With the axial chirality, as well as the configuration at C-3 established for these two compounds the question of the configuration at C-3 of $\mathbf{3}$ and $\mathbf{4}$ was addressed. In order to make these determinations, the comparison of the $\mathrm{H}$ NMR spectra in different solvents was very useful. Particularly, the spectra obtained in chloroform and benzene. Tables 1-4 show selected $\mathrm{H}$ and C NMR data obtained from the four peroxisomicines; only the signals of the atoms used in this discussion are shown.

Table 1. Selected ${ }^{1} \mathrm{H}$ NMR data of Peroxisomicines (400.13 $\mathrm{MHz}$, in $\mathrm{CDCl}_{3} 100 \% \mathrm{~d}, 25{ }^{\circ} \mathrm{C}$ ) 


\begin{tabular}{|c|c|c|c|c|}
\hline & $\begin{array}{c}\mathrm{PA} 1, \delta(\mathrm{ppm}) \\
J \text { in } \mathrm{Hz} \\
\end{array}$ & $\begin{array}{c}\mathrm{PA} 2, \delta(\mathrm{ppm}) \\
J \text { in } \mathrm{Hz} \\
\end{array}$ & $\begin{array}{c}\mathrm{PA} 3, \delta(\mathrm{ppm}) \\
J \text { in } \mathrm{Hz} \\
\end{array}$ & $\begin{array}{c}\mathrm{PA} 4, \delta(\mathrm{ppm}) \\
\quad J \text { in } \mathrm{Hz}\end{array}$ \\
\hline $\mathrm{H}-2$ & $2.90(\mathrm{AB})$ & $2.91(\mathrm{AB})$ & $2.91(\mathrm{~A}$ & $\begin{array}{l}2.94(\mathrm{~d}, 18.8) \\
2.88(\mathrm{~d}, 18.4)\end{array}$ \\
\hline H-4 & $\begin{array}{l}3.20(\mathrm{~d}, 16.3) \\
3.14(\mathrm{~d}, 16.2)\end{array}$ & 3.17 (AB) & $\begin{array}{l}3.19(\mathrm{~d}, 16.5) \\
3.15(\mathrm{~d}, 16.5)\end{array}$ & $3.17(\mathrm{AB})$ \\
\hline Me-3 & $1.52(\mathrm{~s})$ & $1.51(\mathrm{~s})$ & $1.52(\mathrm{~s})$ & $1.51(\mathrm{~s})$ \\
\hline H-2' & $2.88(\mathrm{AB})$ & $2.89(\mathrm{AB})$ & $\begin{array}{l}2.94(\mathrm{~d}, 18.3) \\
2.79(\mathrm{~d}, 17.7)\end{array}$ & $\begin{array}{l}2.84(\mathrm{~d}, 16) \\
2.80(\mathrm{~d}, 17)\end{array}$ \\
\hline H-4'ax & $2.93(\mathrm{~d}, 16.7)$ & $2.96(\mathrm{~d}, 16.6)$ & $2.77(\mathrm{~d}, 16.2)$ & 2.80 (d. 17.0) \\
\hline H-4'ec & $2.75(\mathrm{~d}, 16.7)$ & $2.79(\mathrm{~d}, 16.6)$ & $2.86(\mathrm{~d}, 18.7)$ & $2.88(\mathrm{~d}, 18.4)$ \\
\hline Me-3' & $1.35(\mathrm{~s})$ & $1.36(\mathrm{~s})$ & $1.34(\mathrm{~s})$ & $1.34(\mathrm{~s})$ \\
\hline
\end{tabular}

Table 2. Selected ${ }^{1} \mathrm{H}$ NMR data of Peroxisomicines (400.13 MHz, in $\mathrm{C}_{6} \mathrm{D}_{6} 99.95 \% d, 25^{\circ} \mathrm{C}$ )

\begin{tabular}{ccccc}
\hline & PA1, $\delta(\mathrm{ppm})$ & PA2, $\delta(\mathrm{ppm})$ & PA3, $\delta(\mathrm{ppm})$ & PA4, $\delta(\mathrm{ppm})$ \\
& $J$ in Hz & $J$ in Hz & $J$ in Hz & $J$ in Hz \\
\hline $\mathrm{H}-2$ & $2.54(\mathrm{~d}, 17.4)$ & $2.53(\mathrm{~d}, 16.5)$ & $2.53(\mathrm{~d}, 16.9)$ & $2.52(\mathrm{~d}, 17)$ \\
$\mathrm{H}-2$ & $2.28(\mathrm{~d}, 17.4)$ & $2.24(\mathrm{~d}, 17.8)$ & $2.26(\mathrm{~d}, 17.5)$ & $2.24(\mathrm{~d} 17.4)$ \\
& $2.60(\mathrm{AB})$ & $2.62(\mathrm{~d}, 15.9)$ & $2.62(\mathrm{AB})$ & $2.64(\mathrm{~d}, 16)$ \\
$\mathrm{H}-4$ & $2.53(\mathrm{~d}, 16.5)$ & & $2.58(\mathrm{~d}, 16.7)$ \\
Me-3 & $0.99(\mathrm{~s})$ & $0.96(\mathrm{~s})$ & $0.99(\mathrm{~s})$ & $0.97(\mathrm{~s})$ \\
$\mathrm{H}-2^{\prime}$ & $2.56(\mathrm{~d}, 17.5)$ & $2.53(\mathrm{~d}, 16.5)$ & $2.60(\mathrm{~d}, 16.2)$ & $2.53(\mathrm{~d}, 16.9)$ \\
$\mathrm{H}-2^{\prime}$ & $2.33(\mathrm{~d}, 17.5)$ & $2.29(\mathrm{~d}, 16.3)$ & $2.39(\mathrm{~d}, 17.4)$ & $2.36(\mathrm{~d}, 17.3)$ \\
$\mathrm{H}-4$ & $2.94(\mathrm{~d}, 16.4)$ & $2.90(\mathrm{~d}, 16.4)$ & $2.959 \mathrm{~d}, 16.2)$ & $2.93(\mathrm{~d}, 16.1)$ \\
$\mathrm{H}-4$ & $2.83(\mathrm{~d}, 16.9)$ & $2.81(\mathrm{~d}, 16.5)$ & $2.73(\mathrm{~d}, 17.4)$ & $2.72(\mathrm{~d}, 17.4)$ \\
Me-3' & $0.93(\mathrm{~s})$ & $0.87(\mathrm{~s})$ & $0.99(\mathrm{~s})$ & $0.97(\mathrm{~s})$ \\
\hline
\end{tabular}

* Signals overlapped with solvent signal's

Table 3. Selected ${ }^{13} \mathrm{C}$ RMN data of Peroxisomicines $\left(100.26 \mathrm{MHz}\right.$, in $\mathrm{CDCl}_{3} 100 \% d, 25^{\circ} \mathrm{C}$ )

\begin{tabular}{ccccc}
\hline C & PA1 & PA2 & PA3 & PA4 \\
\hline 3 & 71.147 & 71.087 & 71.117 & 71.109 \\
4 & 43.223 & 43.308 & 43.281 & 43.297 \\
Me3 & 29.251 & 29.121 & 29.212 & 29.149 \\
$3^{\prime}$ & 70.896 & 70.906 & 70.415 & 70.450 \\
$4^{\prime}$ & 41.030 & 41.114 & 41.715 & 41.700 \\
Me3' $^{\prime}$ & 29.328 & 29.201 & 29.212 & 29.149 \\
\hline
\end{tabular}


Table 4. Selected ${ }^{13} \mathrm{C}$ NMR data of Peroxisomicines $\left(100.26 \mathrm{MHz}\right.$, in $\left.\mathrm{C}_{6} \mathrm{D}_{6} 99.95 \% d, 25{ }^{\circ} \mathrm{C}\right)$

\begin{tabular}{ccccc}
\hline C & PA1 & PA2 & PA3 & PA4 \\
\hline 3 & 70.56 & 70.57 & 70.56 & 70.57 \\
4 & 43.30 & 43.28 & 43.30 & 43.29 \\
Me3 & 29.02 & 29.06 & 29.02 & 29.01 \\
$3^{\prime}$ & 70.56 & 70.52 & 70.28 & 70.23 \\
$4^{\prime}$ & 41.63 & 41.64 & 42.35 & 42.37 \\
Me3' $^{\prime}$ & 29.26 & 29.20 & 29.07 & 29.06 \\
\hline
\end{tabular}

Figure 3 shows the aliphatic region of interest of the ${ }^{1} \mathrm{H}$ NMR spectra in chloroform. The split pattern of the signals assigned to H-4 in $\mathbf{1}$ and $\mathbf{3}$ resulted identical; similarly, the split pattern of the signals assigned to $\mathrm{H}-4$ in $\mathbf{2}$ and $\mathbf{4}$ are closely related. These results suggested that $\mathbf{3}$ has the same configuration at C-3 as $\mathbf{1}$, and $\mathbf{4}$ has the same configuration at C-3 as $\mathbf{2}$.

\section{H-4}

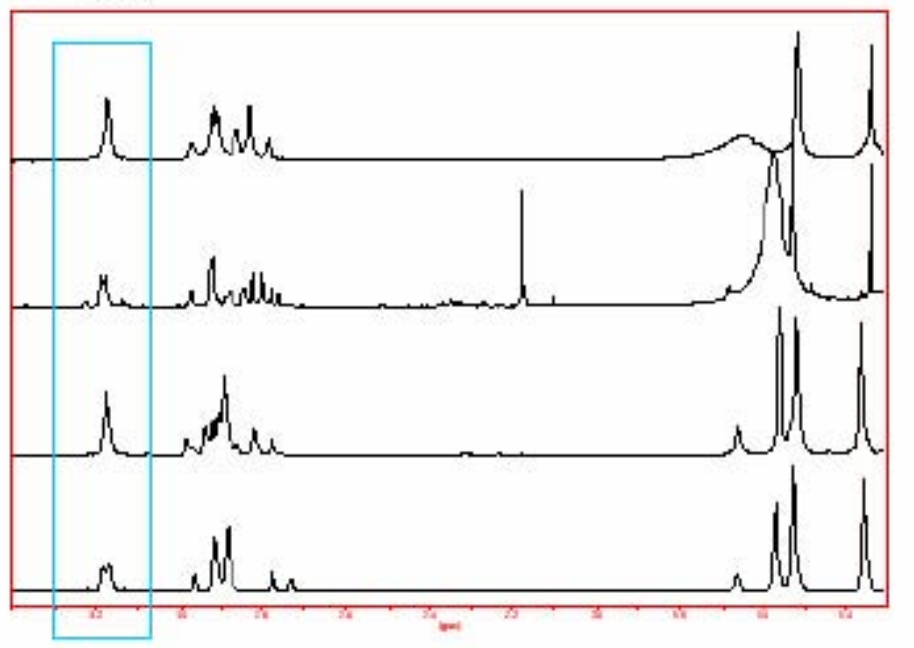

PA4

PA3

PA2

PAl

Figure 3. ${ }^{1} \mathrm{H}$ NMR of peroxisomicines, in $\mathrm{CDCl}_{3} 100 \% d\left(25^{\circ} \mathrm{C}\right)$, at $400 \mathrm{MHz}$.

From the spectra obtained in benzene (Figure 4), it is possible to observe a similar pattern for the signals originated from H-4' in $\mathbf{1}$ and $\mathbf{2}$ on one hand, and for the signals originated from $\mathrm{H}-4$ ' in 3 and 4, on the other. As we already knew that 1 and $\mathbf{2}$ have the same configuration at C-3' (the same applies for 3 and 4). These observations confirm that the pattern of the ${ }^{1} \mathrm{H}$ MNR spectra resembles in some aspects the difference in the stereochemistry at C-3'. The same observation can be done with the signal displayed by H-2', as seen on figure 3. Moreover, the 
chemical displacements of $\mathrm{H}-2$ in the spectrum obtained from $\mathbf{1}$ and $\mathbf{3}$ on one side and $\mathbf{2}$ and $\mathbf{4}$ on the other side are almost identical.

Therefore, all these observations suggest that PA3 (3) is the P, 3S, 3'R- isomer and PA4 (4) is the $\mathrm{P}, 3 \mathrm{R}$, 3' $^{\prime} \mathrm{R}$-isomer.
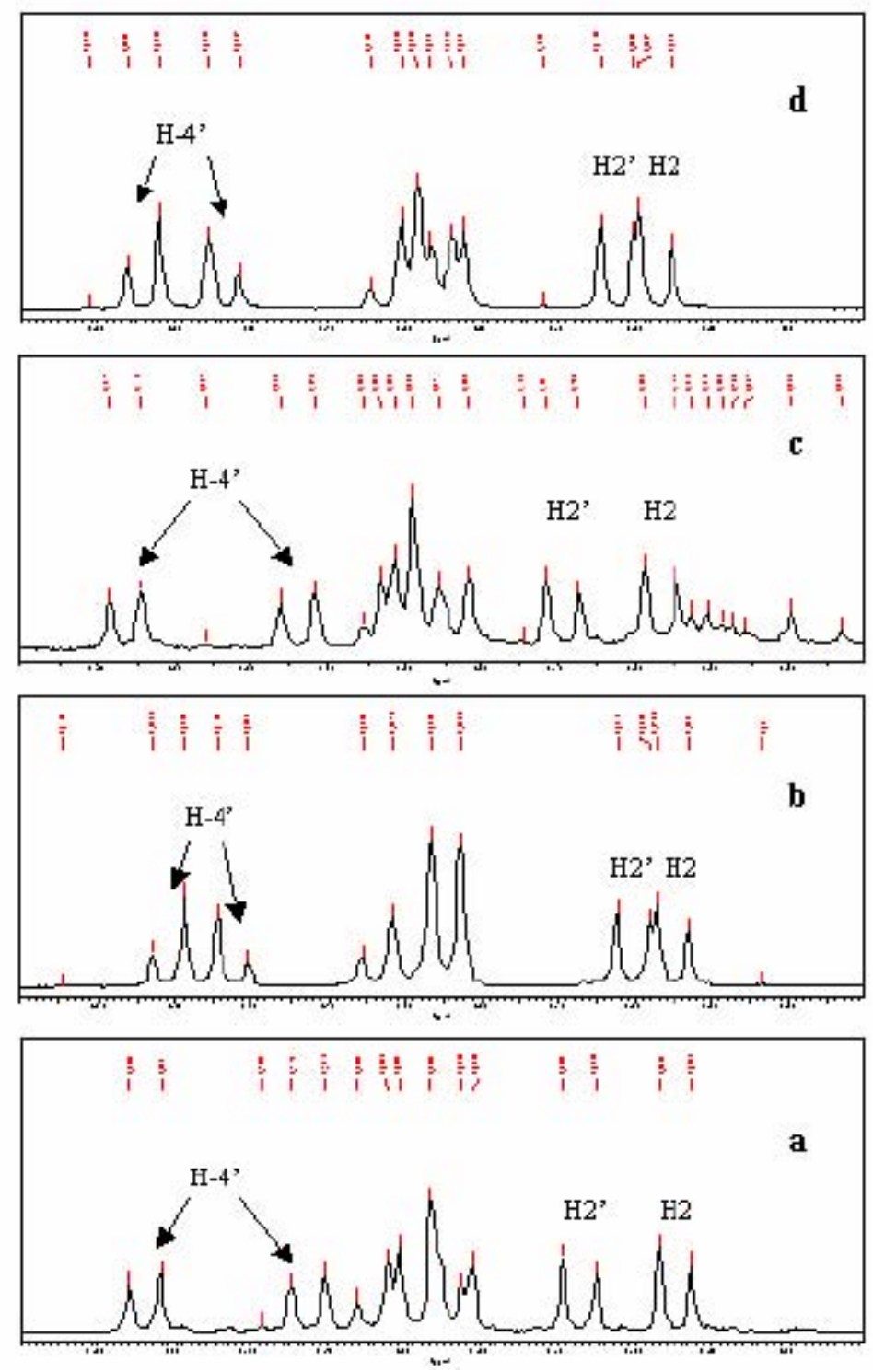

Figure 4. ${ }^{1} \mathrm{H}$ RMN of a) 4, b) 2, c) 3, d) 1 in benzene-d6, methylene region.

Exposure of Chang liver and HepG2 cells (benign and neoplastic cell respectively) to 1, 2, 3 and 4 resulted in a concentration-dependent increase in the suppression of mitochondrial metabolic activity. Toxicity studies showed that all compounds tested were cytotoxic. However, a significant difference between the $\mathrm{CT}_{50}$ values of neoplastic and benign cells was found only with 1 and 3 (Table 5). This behavior suggests that the isomers with the same configuration at $\mathrm{C}$ 3 ( as observed by $\mathrm{H}$ NMR results) had similar activity leading us to conclude the this portion of 
the molecule could be responsible for the selectivity displayed by these substances.

Table 5. $\mathrm{CT}_{50}$ values $(\mu \mathrm{g} / \mathrm{mL})$ obtained after $72 \mathrm{~h}$ exposure of Chang liver cells and Hep G2 cells to peroxisomicines A1, A2, A3, and A4. Cytotoxicity was assessed by the MTT test. The experimental treatments are described in the Methods. ${ }^{*} P<0.05 ; \mathrm{n}=4$

\begin{tabular}{lcl}
\hline \multicolumn{3}{c}{$\mathrm{CT}_{50} \mu \mathrm{g} / \mathrm{mL}$} \\
\hline & Chang Liver Cells & HepG2Cells \\
\hline PA1 & 2.5 & $0.16^{*}$ \\
PA2 & 2.5 & 2.5 \\
PA3 & 5.0 & $1.24^{*}$ \\
PA4 & 1.25 & 1.25 \\
\hline
\end{tabular}

\section{Conclusions}

A new peroxisomicine-type dimeric hydroxyanthracenone was isolated from semipolar extracts of K parvifolia. According to previous results on the stereochemistry of PA1 (1) and PA2 (2), the new compound, named as peroxisomicine A4 (4), could be identified as the P,3R,3'R-isomer. Comparison of the $\mathrm{H}$ NMR patterns of the spectra obtained from the four peroxisomicines in different solvents, was a useful tool for the assignment of the stereochemistry at C-3 in this isomer. All the peroxisomicines were cytotoxic to Chang Liver Cells and Hep G2 Cells. However, only PA3 (3) showed the selective toxicity displayed by PA1 (1). Considering these results, it could be suggested that the observed selectivity of these compounds is related to the stereochemistry at C-3. Further studies are necessary to confirm these preliminary results.

\section{Experimental Section}

General Procedures. Analytical HPLC was carried out on a HP 1090 (DAD detector) with a C18 column $(100 \times 2.1 \mathrm{~mm}, 5 \mu \mathrm{m})$; elution was accomplished with a mixture of $\mathrm{MeOH}, \mathrm{H}_{2} \mathrm{O}_{\text {, }}$ $\mathrm{CH}_{3} \mathrm{CN}$, and HOAc according to methodology previously described. ${ }^{11}$ Preparative HPLC was accomplished on a Water prep LC 200, column 10 × $100 \mathrm{~mm}$ Guard Pak ${ }^{\mathrm{TM}}$ Cartridge $\mu$ Bondapak $^{\text {TM }}$ C-18, $10 \mu \mathrm{m}$. Purification of PA4 was done using a LiChoprep RP-18 $(40-63 \mu \mathrm{m})$ pre-packed column.. Mass spectra were obtained on a HP 5985 mass spectrometer. Melting points were determined with Electrothermal 9100 instrument. $\mathrm{H}$ and ${ }^{13} \mathrm{C}$ NMR spectra were obtained on a Bruker DPX-400 at 400.13 and $100.62 \mathrm{MHz}$ respectively, with 5mm multinuclear probe, temperature controller, using $\mathrm{CDCl}_{3}$ and $\mathrm{C}_{6} \mathrm{D}_{6}$ as solvents. nOe differential experiments were carried out with $\mathrm{CDCl}_{3} 100 \%$ deuterated and in Argon deareated samples. In order to assign 
all signals observed, HMBC experiments were optimized for $J=7$ and $9 \mathrm{~Hz}$. CD spectra were made in methanol on a spectropolarimeter Jasco J-720. Molecular modeling was done with MacSpartan plus program using AM1 semi-empirical calculations.

Plant material. The species was collected in México (Los Mochis Sinaloa, September 1992). The plant was identified by Dr. Rafael Fernández Nava (IPN, México). A voucher specimen was deposited at the IPN under the number 3595 (ENCB).

Extraction and isolation. Peroxisomicines A1, A2, and A3 were isolated from K. parvifolia and were purified in our laboratory by the method previously described. Identity was confirmed by spectral analysis. Isolation of $\mathrm{PA}_{4}$ was carried out in the following way. Air-dried and powdered whole fruits $(1 \mathrm{Kg})$ were defatted three times with n-hexane $(3 \times 2 \mathrm{~L})$, and then extracted with EtOAc ( $3 \mathrm{X} 1 \mathrm{~L})$ at room temperature. The combined EtOAc extracts were evaporated under reduced pressure at $38^{\circ} \mathrm{C}$ to dryness. The residue was redissolved in Chloroform $(25 \mathrm{~mL})$ and precipitated with $n$-hexane to yield $28 \mathrm{~g}$ of a yellow powder. This was extracted with $\mathrm{MeOH}(2$ $\mathrm{X} 200 \mathrm{~mL}$ ) and the methanolic extract was evaporated to dryness, redissolved in chloroform and reprecipitated with petroleum ether, to obtain $7 \mathrm{~g}$ of a yellow powder containing principally compounds 1-4 This powder was fractionated by preparative HPLC with $\mathrm{MeOH}-\mathrm{H}_{2} \mathrm{O}(70: 30)$ containing $1 \%$ of acetic acid. Analytical HPLC of the fraction number one revealed a 10:1 mixture of 2 and 4; this mixture was further separated by means of HPLC under isocratic conditions consisting of $50 \%$ of $\mathrm{MeOH}$ and $50 \%$ of water, to furnish an enriched fraction of compound 4. This compound was finally purified by low pressure chromatography on Lobar C18 using $\mathrm{MeOH}-\mathrm{H}_{2} \mathrm{O}$ (7:3) as eluent, to yield $10 \mathrm{mg}$ of compound 4 pure. Purity of the compound was assessed by means of analytical HPLC.

Peroxisomicine A4. Yellow powder, mp 160-163 ${ }^{\circ} \mathrm{dec},[\alpha]_{\mathrm{D}}-4.7^{\circ}(\mathrm{MeOH}, 0.05)$; ${ }^{1} \mathrm{H}-\mathrm{NMR}$ $\left(400 \mathrm{MHz}, \mathrm{CDCl}_{3}\right) \delta 1.34(3 \mathrm{H}, \mathrm{s}), 1.51(3 \mathrm{H}, \mathrm{s}), 2.80(2 \mathrm{H}, \mathrm{d}, J=17), 2.84(1 \mathrm{H}, \mathrm{d}, J=16), 2.88$ $(2 \mathrm{H}, \mathrm{d}, J=18.4), 2.94(1 \mathrm{H}, \mathrm{d}, J=18.8), 3.17(2 \mathrm{H}, \mathrm{AB}), 6.71(1 \mathrm{H}, \mathrm{d}, J=8.3), 6.87(1 \mathrm{H}, \mathrm{d}, J=$ 7.7), $7.14(1 \mathrm{H}, \mathrm{s}), 7.32(2 \mathrm{H}, \mathrm{s}), 7.35(1 \mathrm{H}, \mathrm{t}, J=8.1), 10.00(1 \mathrm{H}, \mathrm{s}), 10.04(1 \mathrm{H}, \mathrm{s}), 16.06(1 \mathrm{H}, \mathrm{s})$, $16.45(1 \mathrm{H}, \mathrm{s}) ; \quad \mathrm{C}-\mathrm{NMR}\left(100 \mathrm{MHz}^{13} \mathrm{CDCL}_{3}\right) \delta 203.188,203.499,165.485,165.964,158.670$, $154.664,139.116,139.346,135.144,135.581,132.940,132.792,125.180,119.999,118.617$, 118.708, 116.986, 113.083, 112.977, 111.411, 109.768, 109.221, 70.450, 71.109, 51.301, 50.740, 43.297, 41.700, 29.149, 29.149; $\mathrm{MS} \mathrm{m} / \mathrm{z}: 515\left(\mathrm{M}^{+}+1,100 \%\right), 497\left(\mathrm{M}^{+}+1-\mathrm{H}_{2} \mathrm{O}, 45 \%\right), 479$ $\left(\mathrm{M}^{+}+1-2 \quad \mathrm{H}_{2} \mathrm{O}, 18 \%\right.$ ), 239 (monomer, 22\%); HRMS Calcd. $\mathrm{C}_{30} \mathrm{H}_{26} \mathrm{O}_{8}$ 514.1628. Found: 514.1642.

Cytotoxicity. For cytotoxicity studies, Chang liver and HepG2 cells (ATCC Manassas, VA, USA), cultured in 96 -well plates $(1 \times 10$ cells $/ \mathrm{mL})$ were treated with peroxisomicines A1, A2, A3, and A4 dissolved in ethanol and then diluted with medium. Each compound was evaluated at 12 different concentrations, ranging from 0.1 to $160 \mu \mathrm{g} / \mathrm{mL}$ according to previous cytotoxicity studies. $^{12}$ Four wells were used for each concentration tested. Culture plates were incubated at 37 
${ }^{\circ} \mathrm{C}$ for $72 \mathrm{~h}$. Control wells were exposed to $0.1 \%$ alcohol alone. PA1 was the positive control. Cytotoxicity was determined by the reduction of MTT by mitochondrial dehydrogenase enzymes of viable cells to a blue formazan product, which was measured spectrophotometrically at 570 $\mathrm{nm}$ according to Mosmann. Absorbance was expressed as a percentage of the control absorbance (100\%) obtained from wells containing no toxic agent. The concentration producing $50 \%$ cytotoxicity $\left(\mathrm{CT}_{50}\right)$ for normal and malignant cells was calculated following the method of Ekwall et al. ${ }^{14}$ as the geometrical mean of total cytotoxic concentration $\left(\mathrm{CT}_{100}\right)$ and highest nontoxic concentration tested $\left(\mathrm{CT}_{0}\right)$. The procedure was repeated three times in separate experiments. Comparisons between $\mathrm{CT}_{50}$ values for normal and malignant cells were made using Student's t-test with $\mathrm{P}<0.05$ considered to be significant.

\section{Supplementary Information Available}

The complete ${ }^{1} \mathrm{H}$ NMR and ${ }^{13} \mathrm{C}$ NMR tables for the four peroxisomicines can be found in the supplementary material.

\section{Acknowledgements}

We wish to thank CONACYT (México) for financial support in the form of a fellowship for V.R.G.

\section{References}

1. Waksman, N.; Martínez, L.; Fernández, R., Rev. Latinoam. Quim. 1989, 20, 27.

2. Fernández-Nava, R. Anal. Inst. Biol. Univ. Nac. Autón. México, Ser. Bot. 1992, 63, 1.

3. Piñeyro-López, A.; Waksman, N. In The Antracenones of the Karwinskia genus. Chemistry, structure and Biological Activity. Studies in Natural Products Chemistry, Bioactive Natural Products (C). 1 Edn.; Elsevier, 2000; Vol. 22, pp 555-606.

4. Dreyer, D. L.; Arai, I.; Bachman, C. D.; Anderson, W. R., Jr.; Smith, R. G.; Doyle Daves, G., Jr. J. Am. Chem. Soc. 1975, 97, 4985.

5. Rivas-Galindo, V.; Waksman, N. Nat. Prod. Lett. 2001, 15, 243.

6. Waksman, N.; Benavides-Cortez, G.; and Rivas-Galindo, V. Phytochemistry 1999, 50, 1041.

7. Piñeyro-López, A.; Martínez, L.; González, R. Toxicology 1994, 92, 217.

8. Martínez, F.; Qing-Zeng, G.; Garza, L.; Piñeyro-López, A.; Tomei, D.; Umansky, S. Drug Chem. Toxicology 2001, 23, 287.

9. Pérez, L.; Rivas-Galindo, V.; Ramírez-Durón, R.; Piñeyro-López, A.; Waksman, N. Ciencia 
UANL 2003, Vol. VI, No. 2, 196.

10. Pérez, A.; Ramírez-Durón, R.; Piñeyro-López, A.; Waksman, N.; Reichert, M.; Bringmann, G. Tetrahedron 2004, 60, 8547.

11. Salazar, M.L.; Piñeyro-López, A.; Waksman, N. J. Liq. Chromatogr. Relat. Technol. 1996, 19, 1391.

12. Garza-Ocañas, L.; Hsieh, G. C.; Acosta, D.; Torres-Alanís, O.; Piñeyro-López, A. Toxicology 1992, 73, 191.

13. Mosmann, T. J. Immunol. Methods 1983, 65, 55.

14. Ekwall, B.; Johansson, A. Toxicol. Lett. 1980, 5, 299. 